\title{
Some remarks on the depopulation of Dacia during the reign of Trajan and the reliability of written sources
}

\author{
Mateusz Żmudziński \\ Institut of Archaeology, University of Wrocław, Poland \\ Email: mateusz.zmudzinski@uwr.edu.pl
}

\begin{abstract}
:
Some remarks on the depopulation of Dacia during the reign of Trajan and the reliability of written sources.

At the end of the fourth century C.E. Eutropius wrote that during the Dacian wars, under the reign of Trajan, Dacia had been completely depopulated. The article confronts his opinion with archaeological sources. They show that the ancient author drew a much simplified picture of the phenomena. The Dacians clashed the tribal elite and tens of thousands were killed and captured. Thousands of people were displaced. In some places there were emptiness settlements. Fortresses and sanctuaries were abandoned forever. However, this does not mean the complete disappearance of the native population. Dacians lived in the villages. Only some of them made careers and left behind written sources. Archaeological sources, however, indicate the massive presence of them as farmers and hired workers.
\end{abstract}

Keywords: Depopulation, Dacia, Trajan, Eutropius, Archaeology 


\section{DISCUSSION OF THE PROBLEM}

The conquest of Dacia by the Romans in the beginning of the $2^{\text {nd }}$ Century A.D. and its consequences have been studied by many researchers ${ }^{1}$. I would like to focus on the question of one of these consequences, depopulation, and to show the important differences resulting from the interpretation of written and archaeological sources. The bloody and extraordinarily tragic run of the Dacian wars under Trajan is an incontestable fact ${ }^{2}$. I.A. Oltean has observed the dire events which accompanied the conquest and the foundation of the Roman provinces ${ }^{3}$. The problem is that interpretation of these facts and their consequences by the Ancients as well as in later times often escaped the rational analysis of the researchers and was used as an element of propaganda. In this paper, I would like to try to explain the serious misunderstanding which arose in this matter. Archaeological finds obviously show that in the second Century A.D., just before the Roman invasion, the Dacian territories were densely populated. People lived both in many villages and in strongholds which seem to have formed a system similar to a chain of fortified cities ${ }^{4}$. Good examples of densely populated areas in pre-Roman Dacia are found on the middle course of the Maris River ${ }^{5}$. The Dacian wars and the conquest of these territories by the Roman armies under the reign of Trajan caused enormous settlement changes. These phenomena and the available data about them should be analysed, because the information from written sources related to this dramatic period is not checked against archaeological data. Researchers who use them separately are likely to come to completely different conclusions. Archaeological sources can be blamed for being fragmentary, random, dependent on their state of preservation, or misinterpreted by the researchers. The other kind of information is provided by the Ancient historiographers' works. Written sources about Roman Dacia at this time of the conquest have been carefully collected and analysed by D. Ruscu ${ }^{6}$. A key text is the „Breviarium ad urbe condita” by Eutropius $^{7}$. When commenting the Roman conquest of Dacia and its consequences, this Ancient historian explains that, because of the wars, the population of these territories

\footnotetext{
${ }^{1}$ E.g. DAICOVICIU 1938, 37-38; DAICOVICIU 1972, 329-336; RUSSU 1981, 165-201; GUDEA/ LOBÜSCHER 2006, 23 , NEMETI/ DANA 2019, 11-16.

${ }^{2}$ STEFAN 2005.

${ }^{3}$ Cf. OLTEAN 2007, 1-3.

${ }^{4}$ CF. CRIȘAN 2000: 20 ET AL.; DENSUȘIANU 1986, 30.

${ }^{5}$ GHEORGHIU 2005: 11 Et al.

${ }^{6}$ RUSCU 2002, 48-67; RUSCU 2004, 75-85.

${ }^{7}$ EUTROPIUS 8.6,2.
} 
completely disappeared and new settlers had to be called in from practically all parts of the Empire to repopulate them. The problem is that Eutropius lived and wrote not in the time of the Dacian wars, at the beginning of the $2^{\text {nd }}$ Century, but around the year 370 A.D., under Emperor Valens. His work, then, is not an objective description of personally known events, but a kind of history handbook for barbarian soldiers who needed to learn some basic information about the history of the country where they had been sent to live. Eutropius' work lacks of accuracy and is not reliable ${ }^{8}$. Two and a half century after the facts, Eutropius was not able to check the data in his possession. He had only partial sources, and his work aimed to show a clear, legible and unambiguous picture of the history, without worrying about tiny nuances which would not be noticed in the rest of the Empire. This explains his simplification, when he speaks of total depopulation of Dacia as a result of the wars. But according to D. Ruscu, such a thing could actually happen, as shown, for example, by the information about the almost total extermination of the Getae by Trajan ${ }^{9}$. But when comparing archaeological data with such descriptions, we note that the ethnic cleansing during the Dacian wars and their subsequent depopulation could apply only to selected communities and parts of the created provinces.

Ethnic cleansing, warriors' deaths, deportation of thousands of prisoners for gladiatorial games and slave labour in Rome, and forced recruitment of men for the military units stationed in other provinces are not questioned. The dramatic and extremely bloody course of the Dacian wars is an incontestable fact ${ }^{10}$. Ten thousand gladiators, of whom the majority were probably prisoners of war, took part in the games organized to celebrate the victory ${ }^{11}$. The number of captured people itself is estimated to about 50,000. The gigantic public works realised in the imperial capital after the wars, for example the construction of Trajan's Forum, the reconstruction of the Circus Maximus, the completion of the Esquiline Baths, the construction of a road through the Pontine Marshes, an aqueduct and an extended harbour in Ostia, and the development of Ancona harbour seem to witness to forced labour of thousands of Dacian prisoners ${ }^{12}$. Breadwinners' deaths, crops devastation and burned houses, in the harsh climate of the Carpathian, probably entailed the deaths of numerous warriors' widows, children and infirm elderly. It is impossible to estimate how many people were killed in the

\footnotetext{
${ }^{8}$ BRAVO/ WIPSZYCKA, 1985, 71.

${ }^{9}$ RUSCU 2004, 77.

${ }^{10}$ CF. DAICOVICIU 1972, 329-336.

${ }^{11}$ CIECHANOWICZ 1987, 213.

${ }^{12}$ CIECHANOWICZ 1987, 214.
} 
war, and how many died later, homeless and deprived of their property, as a result of hunger, cold weather and disease. Archaeological research so far has not uncovered mass graves of defenders and their families. But certainly thousands of Dacians were killed during the war or died in the winter shortly afterwards. Subsequent local population voids were due not only to the death of the participants of the war, but also to a demographic gap of some generations due to the decimation of people in childbearing age. However, as modern demographers note, mortality depends on factors both biological and social, and periods of rapid change and increased mortality are usually followed by periods of increased demographic growth ${ }^{13}$ Today, we know nothing of the mass rapes committed by the invaders on Dacian women and the later births of children as a consequence. This phenomenon often occurs during wars and children born from rape victims, unless they were abandoned or killed, were raised according to the customs of their mothers. It is possible that some women were treated as captives and married $^{14}$. However, this problem was not in the slightest raised by historians commenting the conquest. Examples of modern wars show that bestialities against women are of a mass nature ${ }^{15}$. It is therefore likely that the Roman victors treated the local women as war booty. It probably was considered as marginal in regard to the tragic events or maybe, like many other atrocities, was seen as a typical side effect of the war, like catching people and turning them into slaves, or looting the conquered populations. Available archaeological data, however, show that despite the terrible and crushing defeat, during the period of the Roman province, Dacians survived in large areas and not only in small enclaves. It seems that they were evacuated from the places where they could effectively defend, mainly fortresses, as well as from areas particularly attractive to newcomers. According to I.A. Oltean, archaeological research confirms the tragic conquest and its effects, such as rapid movement of the local people who were forced to leave their strongholds in the mountains and live in the lowlands ${ }^{16}$. D. Protase, who studied the ancient natives, believes that only a few of them survived the conquest $^{17}$. Part of the people whose elites were massively exterminated could be marginalized in the new society. It is difficult to precisely determine today the scale of the genocide which accompanied the Dacian wars. Preserved archaeological data, however, show that certainly not all of them died. This is evidenced by the remains of Dacian type

\footnotetext{
${ }^{13}$ OKÓLSKI/ FIHEL 2012, 92-96.

${ }^{14}$ WANNER 2010, 24.

${ }^{15}$ CF. BABAR 2016; POLL 2020, 81-115.

${ }^{16}$ OLTEAN 2007, 3.

${ }^{17}$ PROTASE 1980, 27-31.
} 
settlements, their related cremation cemeteries, with graves arranged according to local customs, and finally tons of Dacian pottery found on almost every archaeological site ${ }^{18}$. Small amounts of Dacian pottery are found in the ruins of the Roman villas in almost all regions of Dacia ${ }^{19}$. Interestingly, on the sites interpreted as Dacian from the province period, a vast majority of artefacts are Roman-type products, not Dacian. Only up to $15 \%$ of the pottery found on these sites are Dacian-type ${ }^{20}$. Continued Dacian tradition is noticeable in handicraft as well as, for example, in the burial practice for children, which differs from the Romans $^{21}$. Roman inscriptions from the provincial era seem to indicate that the Dacians lost their elite as a result of the conquest ${ }^{22}$. The centers of former power and local cults never rose again $^{23}$. In local sanctuaries we can not notice any continuity of the pre-Roman. The only possible exception might be the one from Germisara. The argument is not very strong, based on information about presence of a possibly Dacian inhabitant called Decebalus, son of Lucius $^{24}$. After the provinces were settled by immigrants, the Dacians were usually modest, illiterate farmers. Few of them managed to get promoted in the social hierarchy ${ }^{25}$. Presented examples are related to various elements of private life, where people followed only traditions accepted earlier. The richness of these sources shows that Eutropius' testimony is not reliable ${ }^{26}$. But this does not mean that after the wars, there were no areas completely abandoned or inhabited mainly by immigrants. The resettlement of Dacia with about 12,000 free Dacians under the reign of Commodus does not resolve the question, since the presence of Dacians on the analysed areas is visible in the archaeological materials dated from before the reign of this Emperor ${ }^{27}$. It seems that Commodus only filled the population gap or the lack of workers on the local labour market. S. Dumitrascu has observed that in areas where depopulation occurred due to the Dacian wars, including in areas which did not become parts of the province later, dense resettlements of free Dacians often took place as early as the $3^{\text {rd }}$

\footnotetext{
${ }^{18}$ HICA 1999, 84-96; GLODARIU 1981.

${ }^{19}$ OLTEAN 2004, 151-152.

${ }^{20}$ OLTEAN 2004, 160.

${ }^{21}$ MACREA 1969, 290; MITROFAN 1972, 141-162; MARCU 1989, 285-290; BLĂJAN 1990, 283-334.

22 PISO 1993; RUSSU 1977.

${ }^{23}$ WHEELER 2011, 1203.

${ }^{24}$ SZABO 2018,143-145.

${ }^{25}$ WANNER 2010, 24.

${ }^{26}$ CF. ELLIS 1998, 229.

${ }^{27}$ CF. DAICOVICIU 1969, 43.
} 
Century $^{28}$. The current state of research seems to indicate that after the pacification of the Dacians, significant areas East of the River Olt and in parts of the upper Tisza remained uninhabited for a long time ${ }^{29}$. These areas were settled by immigrants from other provinces ${ }^{30}$. Permanent depopulation also affected areas in the lower regions of the Danube River near present-day Bucharest. According to C. Daicoviciu, Dacian settlements in the valley of the lower Danube, in the region of Bucharest, declined because of the war and never recovered. This researcher believes that Eutropius' statement ${ }^{31}$ is not exaggerated in the case of some $\operatorname{areas}^{32}$ : in some - but not all - cases, Eutropius and later authors after him could be right. I. Glodariu has noticed that after the conquest, the Romans allowed the colonization of much of the ancient Dacian settlements ${ }^{33}$. The only exception is Sarmizegetusa Dacica where a new Roman city with a similar name was built in the surrounding. What's more, it seems that the population of these settlements was not only made up with newcomers and their descendants, but also with Dacians. According to D. Protase, although Dacian settlements disappeared in the areas of ancient fortresses, they survived on a number of settlements ${ }^{34}$. In the $3^{\text {rd }}$ Century, Banat areas were so romanized that a significant part of the local settlements can be considered a continuation of the Roman provincial tradition. The pottery produced and used there and other products are typically Roman, not Dacian ${ }^{35}$. In Napoca, about $10 \%$ of pottery sherds were made by descendants of the conquered population. It is possible that some of the pots are packaging for food brought from the countryside to the market. The preserved inscriptions show that although the core of Roman Dacia's municipal elites was made up with newcomers and their descendants, in the founded cities, Dacians also reached a whole range of positions, which is clearly noticeable in the inscriptions ${ }^{36}$. Only about $2 \%$ of the inscriptions of the Dacian territory are related to Traco-Dacian population ${ }^{37}$. However, the proportion of these inscriptions seems to show not so much the number of people of Dacian origin who lived in the cities of the province, but rather that they played no prominent role in

\footnotetext{
${ }^{28}$ DUMITRAȘCU 1993, 159.

${ }^{29}$ GIURESCU 1980, 54-55.

${ }^{30}$ GINDELE 2010, 156; POP 2006, 97.

${ }^{31}$ EUTROPIUS 8.6.2.

${ }^{32}$ DAICOVICIU 1969, 569

${ }^{33}$ GLODARIU 1987, 133-137.

${ }^{34}$ PROTASE $1977,990-1015$.

${ }^{35}$ BEJAN 2006, 114-121.

${ }^{36}$ MROZEWICZ 1989, 200.

${ }^{37}$ OLTEAN 2004, 152.
} 
the Roman-founded province. According to D. Ruscu, the small amount of inscriptions related to Dacians is largely due to their low social status ${ }^{38}$. The descendants of the conquered local population, as shown by archaeological data, were rather modest farmers, hired workers or miners, and they left not much evidence in written sources. Only a few managed to reach the urban elites and to leave behind some permanent inscriptions. That is why some historians, forgetting about archaeological data and their significance, almost uncritically and unthinkingly consider Eutropius' text as a completely safe and reliable testimony for the total extermination of Dacians by the Roman army. The Dacians, however, are known from inscriptions from other regions of the Empire, including military diplomas and ostraca in Egypt ${ }^{39}$. In addition, the image is distorted by the uneven state of research of the archaeological sites. For decades, more attention was paid to the excavations in the areas of Roman castles, military camps and cities, which were largely populated by immigrant population or local but very Romanized people, than to the much less attractive poor villages of rural character and to their cemeteries ${ }^{40}$. The poorly developed research on villages and the uneven state of the research can lead to a distorted image of the facts, as if things which were not examined had never existed. However, in these villages, is quite common to find evidence of the Dacians ${ }^{41}$. According to Oltean, research on villages, unlike cities and military camps, is so random that it is impossible to formulate generalizations on this basis. Humble and probably often illiterate farmers, unlike the urban population, did not leave behind tombstones and votive inscriptions. Therefore, looking at the history of the Roman province of Dacia through the prism of the Latin inscriptions can give a false impression that it was inhabited almost exclusively by immigrant population.

In the 20-th century, the drama of the victims of ancient wars discussed here was used for propaganda purposes ${ }^{42}$. The communists, who ruled Romania, tried to present themselves as worthy heirs to the local kings. Today, fortunately, Romanian researchers do not have to engage in supporting political disputes with their research results.

\section{CONSLUSION}

\footnotetext{
${ }^{38}$ RUSCU 2004, 78.

${ }^{39}$ NEMETI/ DANA 2019, 17, 18; DANA 2019, 161-262.

${ }^{40}$ OLTEAN 2007, 143.

${ }^{41}$ OLTEAN 2007, 3.

${ }^{42}$ ELIS 1998, 225.
} 
In conclusion, I believe we can consider that the researchers' image of the consequences of the Dacian wars, among which depopulation of Dacia, is still severely disrupted. Uneven interest of the scientists for different categories of sites could give the impression that the Roman provinces of Dacia were inhabited almost entirely by new immigrants and their descendants. This feeling is strengthened by the poverty and illiteracy of a large part of the ancient rural population, which results in a lack of inscriptions. The frequent use of "trendy" Roman-type items, perhaps considered to be better or nicer, even in rural areas, is conducive to creating the image of a province whose former native population was exterminated. A more accurate and free of ideological accents analysis of the sources shows that the true picture of the phenomena is much more complicated. There were areas permanently depopulated. But apart from the now well-known cities and Roman military camps, there were dozens of villages largely inhabited by Dacians. After stabilization of the situation, some of them came to live in the cities, and occasionally, even gained considerable wealth and became prominent. Without questioning the tragic events surrounding the Roman conquest, or large-scale ethnic cleansing and destruction, it should be recognized, however, that the liquidation of the resistance and the elimination of the local elites was one thing, and the submission of the other social strata, another thing. Plain farmers and craftsmen, although they often lost their most fertile fields and fortified villages, often were able to find themselves in the new reality. Dacian pottery fragments found in the ruins of Roman villas and castles indicate that their residents bought Dacian food or hired local workers. The phenomena discussed in this paper have been used by various ideologues, mainly during the communist period, but it seems that history is slowly moving away from such a manipulation of the sources. Summing up, it should be noted that written sources do not fully reflect the phenomena associated with the effects of ancient wars. Archaeological monuments allow to verify the picture of phenomena. Thanks to them, you can see the scale of the phenomena, as well as the survival of the conquered ethnos.

\section{References}

[1] Babar A. V., Rape as a Continuing Weapon of Psychological Warfare, Suppression \& Subjugation, The International Journal of Indian Psychology 3,2,8, 80- 97.

[2] Bejan A. Contribuţii la istoria şi arheologia Banatului în mileniul I.d. Hr. Şi începtul feudalismului, Timiṣoara. 
[3] Bravo B/ Wipszycka E.: Historiografia antyczna, In: B. Bravo/ A. Krzyżanowska/ A Kunisz/ J. Trynkowski/ E. Wipszycka (eds.), Vademecum historyka starożytnej Grecji i Rzymu, vol. 1, (Warszawa: Państwowe Wydawnictwo Naukowe) 39-126.

[4] Ciechanowicz J. Rzym. Ludzie i budowle. (Warszawa: Państwowy Instytut Wydawniczy).

[5] Crișan V. Dacii din estul Transilvaniei, Covasna.

[6] Daicociu C., La Transylvanie dans l'Antiquité, Bucharest.

[7] Daicoviciu, C., Dacia capta. (Zur Frage der Eroberung und ursprünglichen Organisation Dakiens) in: Dacica. Studii şi articole privid istoria veche a pămîntului Românesc, Cluj,. $561-571$.

[8] Daicoviciu, H., Dacia de la Burebista la cucerirerea romană, Cluj.

[9] Dana D. , Dacians in the provinces of the Roman Empire. An overview /in:/ Nemeti S./ Dana D. (eds.) The Dacians in the Roman Empire. Provicional Constructions, (ClujNapoca: Mega Publishing House), 161-262.

[10] Denşușianu N., Dacia Preistorcă, Bucharest.

[11] Dumitrașcu S.,: Dacia Apuseană, Oradea.

[12] Eck, W. (ed.), Prosopographie und Sozialgeschichte, Kolloquium (Köln: Vienna: Böhlau).

[13] Elis L. 1998: „Terra deserta”: population, politics, and the [de]colonisation of Dacia, World Archaeology 30, 2, 220-237.

[14] Gheorghiu G.,: Dacii pe cursul mijlociu al. Mureșului, Cluj-Napoca.

[15] Gindele R., Die Enwicklung der kaiserzeitlichen Siedlungen im Barbaricum im nordwestlichen Gebiet Rumäniens, Satu Mare.

[16] Giurescu C.C./Giurescu D.C: Geschichte der Rumänen, Bucharest

[17] Glodariu, I.: Aşezari dacice şi daco-romane la Slimnic. Contribuţii la continuitea dacilor în Dacia romană, Bucharest.

[18] Glodariu, I.: Aşezărlile Dacice şi politica de urbanizare Romana, Apulum, ArheologieIstorie - Etnografie 24, 133-137.

[19] Gudea N.,/ Lobüscher T., Dacia. Eine römische Provinz zwischen Karpaten un Schwarzem Meer, Mainz am Rhein.

[20] Hanson W.S. and Haynes I.P (eds,) Roman Dacia : the making of a provincial society, The Journal of Roman Archaeology Supplementary Series 56, Portsmouth, Rhode Island.

[21] Hica I., Aşezarea daco-romană de la Stupini(jud.(jud. Bistriţa Năsăud) In: D. Protase, D. Brudaşku (eds.). Napoca 1880 de ani. De la începtul vieţi urbane, Cluj-Napoca, 25-61. 
[22] Mrozewicz, L., Arystokracja municypalna w rzymskich prowincjach nad Renem i Dunajem w okresie wczesnego cesarstwa (Poznań: Uniwersytet im. Adama Mickiewicza w Poznaniu).

[23] Nemeti S./ Dana D. (eds.) The Dacians in the Roman Empire. Provicional Constructions, (Cluj-Napoca: Mega Publishing House)

[24] Okólski M/ Fihel A..Demografia. Współczesne zjawiska i teorie (Warszawa: Wydawnictwo Naukowe Scholar).

[25] Oltean I., Rural settlement in Roman Dacia: some considerations, In: W.S. Hanson and I.P. Hayes (eds.), Roman Dacia. The making of a provincial society, Journal of Roman Archaeology, Supplementary Series nr 56, Portsmouth, Rhode Island 2004, 143-164.

[26] Oltean I.A., Dacia. Landscape, Colonisation and Romanisation, (London and New York: Routledge).

[27] Pflaum, H.-. and Duval, N. (eds), L'onomastique latine: Actes du Colloque international sur l'onomastique latine organisé à Paris du 13 au 15 octobre 1975, 353-363. (Paris: Éditions du Centre National de la Recherche Scientifique).

[28] Piso I.,: Die sozioale und ethnische Zusammensetzung der Bevölkerung in Sarmizegetusa und Apulum. In: Eck, W. (ed.), Prosopographie und Sozialgeschichte, Kolloquium Köln, 315-337. Vienna: Böhlau.

[29] Poll R., Lynn Nottage's Theatre of Genocide: Ruined, Rape, and Afropessimism Journal of Dramatic Theory and Criticism, 35, 1, Fall 2020, 81-105

[30] Pop H. Descoperirile din epoca romană de la Șimeleul Silvanei, in: Șimelul Silvanei, Monografie arhaeologică, I, Istoricul Cercetrilor, Cluj-Napocă 2006, 97-113.

[31] Protase D., Der Forschungsstand zur der bodenständigen Bevölkerung im römischen Dazien (2-3.Jh), in: Aufstieg und Niedergang der römischen Welt (ANRW) II. 6, (Bonn: De Gruyter) 990-1015.

[32] Protase D., Autohtonii în Dacia 1. Dacia Romana, Bucharest.

[33] D. Protase/ D. Brudaşku (eds.). Napoca 1880 de ani. De la începtul vieţi urbane, ClujNapoca.

[34] Ruscu D. Provincia Dacia în istoriografia antică, Cluj-Napoca.

[35] Ruscu D., The supposed extermination of the Dacians: the literary tradition, In: Hanson W.S. and Haynes I.P. (eds) Roman Dacia : the making of a provincial society, The Journal of Roman Archaeology Supplementary Series 56, Portsmouth, Rhode Island, 7578. 
[36] Russu I.I., L'onomastique de la Dacie Romaine. In: Pflaum, H.-. and Duval, N. (eds), L'onomastique latine: Actes du Colloque international sur l'onomastique latine organisé à Paris du 13 au 15 octobre 1975, 353-363. Paris: Éditions du Centre National de la Recherche Scientifique.

[37] Russu I.I., Etnogeneza românilor. Fondul autohton traco-dacic şi componenta latinoromanică, Bucureşti.

[38] Stefan A.S., Les guerres Daciques de Domitien et Trajan. Architecture militaire, topographie, images et histoire (Collection de L’ École française de Rome 355.

[39] Szabo C., Sanctuaries in Roman Dacia. Matreiality and Religious Experience. (Oxford: Archeopress Roman Archaeology).

[40] Wanner R. Forts, fields and towns: Communities in Northwest Transylvania from the first century $\mathrm{BC}$ to the fifth century $\mathrm{AD}$. Thesis submitted for degree of Doctor of Philosophy

[41] at the University of Leicester. (Tufts University) School of Archaeology and Ancient History

[42] University of Leicester February 2010. http: 1/AppData/Local/Temp/2010WannerRWPhD[1].pdf (Access: 16.05.2021.)

[43] Wheeler, E. L. 2010: Rome's Dacian Wars: Domitian, Trajan, and Strategy on the Danube" Journal of Military History 74 (October 2010): 1185-1227.

[44] Ancient sources: Eutropius. Breviarium. Trans. H.W. Bird. Liverpool: Liverpool University Press, 1993. 